\title{
Un nome
}

Dispersi sono

i pensieri sulla tundra, terra di muschi, dove il vento freme su solitaria croce che cerca un nome.

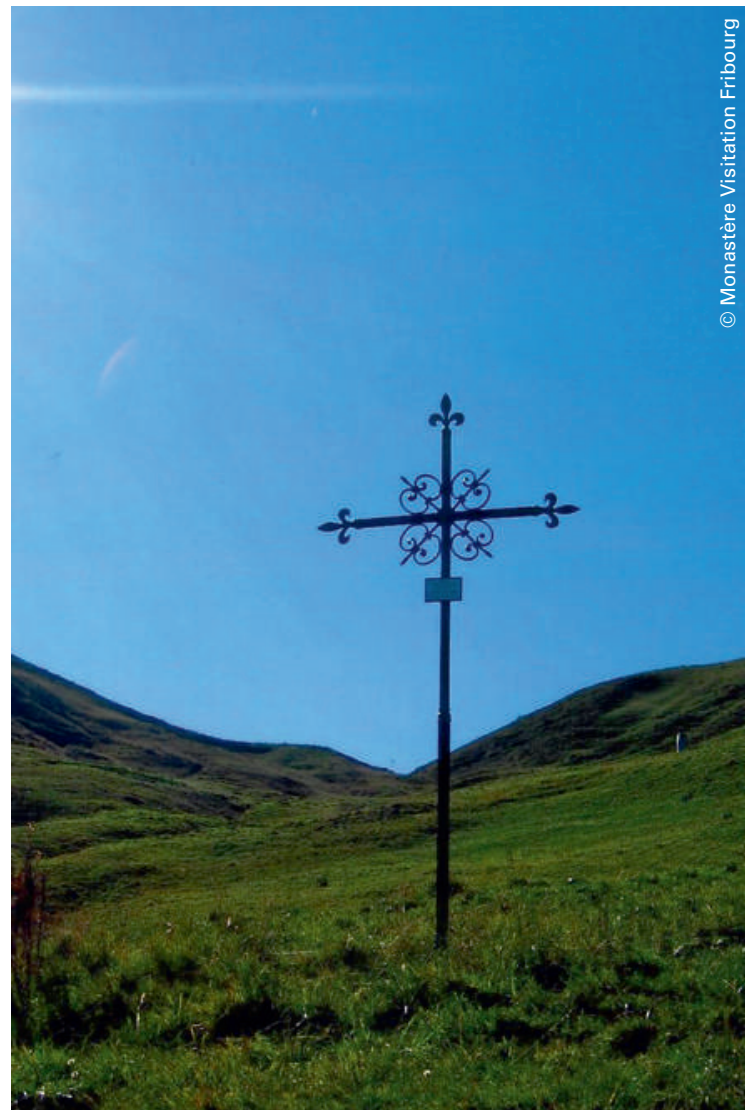

